\title{
Nutritional implications of trans fatty acids during perinatal period, in French pregnant women
}

Oléagineux, Corps Gras, Lipides. Volume 8, Numéro 1, 68-72, Janvier - Février 2001, Dossier : Deutsche Gesellschaft für Fettwissenschaft - Association française pour l'étude des corps gras

Auteur(s) : Carole BOUE, Nicole COMBE, Claude BILLEAUD, Bernard ENTRESSANGLES, Iterg, Laboratoire de lipochimie alimentaire, Université Bordeaux I, France.

Résumé : Certaines études ont mis en évidence le passage des acides gras trans (AGT) à travers le placenta et suggéré leur interférence avec le métabolisme des acides gras essentiels (AGE). Les AGT pourraient donc affecter le développement intra-utérin du fœtus, plus ou moins selon le niveau de consommation en AGT de la mère. Dans ce contexte, l'objectif de cette étude a donc été d'apprécier, chez une population de femmes enceintes françaises, l'éventuel impact de leur consommation en AGT, évaluée par les teneurs en AGT du tissu adipeux, sur certains paramètres du nouveau-né à terme : 1) Composition en acides gras du cordon ombilical (lipides du plasma et phospholipides pariétaux) ; 2) poids à la naissance et périmètre crânien. Les compositions en acides gras des lipides plasmatiques de la mère et du nouveau-né, ainsi que celles des phospholipides du cordon ombilical ont été déterminées par chromatographie en phase gazeuse, couplée à une chromatographie sur couche mince pour les phospholipides. Le passage transplacentaire des AGT est confirmé. Cependant, le pourcentage des acides gras trans (AGT) dans les lipides du plasma maternel $(0,9 \%$ des acides gras totaux) est significativement plus élevé $(p=0,001)$ que celui observé dans les lipides du plasma ombilical $(0,6 \%)$. De plus, le profil en isomères trans des lipides du plasma ombilical différent de celui du plasma maternel, notamment au niveau des isomères trans de l'acide linoléique (18:2 9c12c). Les teneurs en isomères $9 c, 13 t+9 t, 12 t$ et $9 t, 12 c$ sont respectivement 2 et 3 fois supérieures $(p<0,001)$ dans les lipides du plasma ombilical comparées à celles du plasma maternel. Au niveau du cordon ombilical, les isomères trans observés dans le plasma ont tous été retrouvés, à l'exception de l'isomère 16:1 trans, dans les phospholipides (PL) de la paroi et des vaisseaux (artères et veine). Cependant, le taux du mélange d'isomères $9 c 13 t+9 t 12 t$ est significativement plus élevé ( $p$ $<0,001)$ dans les PL des artères que dans ceux de la veine. Dans les PL artériels, le pourcentage de ces isomères trans est négativement corrélé $(r=-0,703, p=0,003)$ à celui de l'acide arachidonique. Toutefois, pour la population française, il n'apparaît aucune corrélation entre le poids ou le périmètre crânien du nouveau-né et les teneurs en AGT dans les lipides du tissu adipeux ou du plasma de la mère.

Mots-clés : acides gras trans, acides gras polyinsaturés à longue chaîne, nutrition fœtale, tissus du cordon ombilical. 
Summary : Some studies have demonstrated the transfer of trans fatty acids (TFA) across the human placenta. It was suggested that TFA might disturb the metabolism of essential fatty acids (EFA) in fetus and consequently might affect intrauterine human growth more or less according to the TFA intake level of the mother. In this context, the objective of this study was to assess, for French pregnant women, possible impact of their TFA intake on parameters of their term infants: 1/ TFA composition of the umbilical cord (plasma lipids and parietal phospholipids), 2/ birth weight and head circumference. The TFA composition of maternal and umbilical plasma lipids, and parietal phospholipids of umbilical cord were determined by gas chromatography, associated with a thinlayer chromatography for the phospholipids. Because TFA content of adipose tissue is a reliable biochemical indicator of the usual TFA intake level, maternal adipose tissue was also analyzed. Trans fatty acid (TFA) percentage was significantly higher $(p=0.001)$ in maternal $(0.9 \%$ of total fatty acids) than in umbilical plasma total lipids $(0.6 \%)$ thus confirming their placental passage. Moreover, trans isomer pattern of cord plasma lipids was different from the maternal's one, especially regarding trans isomers of linoleic acid (9c,12c-18:2). Percentage values of $9 c, 13 t+9 t, 12 t$ and $9 t, 12 c$ isomers were respectively, 2 and 3 times higher $(p<0.001$ ) in umbilical than in maternal plasma (Except trans 16:1 acids). All trans isomers observed in umbilical plasma lipids were detected in both parietal and vessel (vein and arteries) phospholipids of umbilical cord. Nevertheless, 9c13t $+9 t 12 t$ isomer mix level was significantly higher $(p<0.001)$ in artery than in vein TPL. Moreover, in artery TPL, percentage value of $9 c 13 t+9 t 12 t$ isomer mix was inversely correlated $(r=-0.703, p=0.003)$ with arachidonic acid content. Nevertheless, for this French population, there was no relation between either weight or head circumference of newborn and the TFA levels in both adipose tissue and plasma lipids of their mother.

Keywords : trans fatty acids, long-chain polyunsaturated fatty acids, fetal nutrition, umbilical cord tissues.

\section{ARTICLE}

Occurrence of trans fatty acids (TFA) in human tissues depends on their availability in the diet, because humans do not synthesize these fatty acid isomers. It is now well known that trans fatty acids are provided by three different dietary sources: the ruminant fats (milk and dairy products, beef, mutton, tallow) [1], the partially hydrogenated vegetable oils (PHVO) (some margarines, shortenings, bakeries and chips) [2] and to a lesser extent, the refined vegetable oils [3].

Several animal studies, in vivo [4-6] and in vitro experiments in animal tissues [7-10] as well as human fibroblast studies [11] have demonstrated that TFAs impair the microsomal desaturation and chain elongation of essential fatty acids linoleic acid (LA) and alpha-linolenic acid (LNA) to long chain polyunsaturated fatty acids (LC-PUFA). Among all trans isomers, 9t12t-18:2 isomer exerts the strongest impairment of delta6 desaturase activity [4, 12-14]. In adults, inhibitory effect of TFA does not cause serious undesirable health hazards when dietary LA is sufficient $[15,16]$. However, the fetus is very sensitive to factors that can interfere with the synthesis of LC-PUFA, because of an extensive need of arachidonic and docosahexaenoic acids for the development of neurological structures of the brain and retina [17-19] and for the synthesis of eicosanoids [20]. In addition, the biosynthetic activity of LC-PUFA is low in fetus [21]. 
As reported, the level of plasma trans octadecenoic acid was inversely related to levels of LC-PUFA in premature infants [22]. The plasma level of TFA and birth weight were also inversely related. In human fetal tissue collected after abortions at a gestational age varying from 5 to 15 weeks and umbilical venous walls from full-term neonates, there was an inverse relation between trans 18:1 isomer and the n-6 LC PUFA [23]. Weight and head circumference of full-term neonates were also inversely correlated with trans 18:1 acid in umbilical arterial vessel walls.

In this context, it has been suggested that exposure to high levels of TFA during pregnancy may impair the growth of the fetus.

The main objective of this study was to examine the incorporation of TFA into the plasma and red blood cell (RBC) lipids of the umbilical cord blood in relation with TFA composition of the maternal plasma, in order to observe a possible discriminating placental transport of the different trans isomers.

In the same way, the TFA profile of maternal plasma lipids was compared with that of the cord wall, as well as cord vein and artery phospholipids, in order to show a possible selective incorporation of the different trans isomers into lipids of cord tissues.

\section{Material and methods}

\section{Subject and sample collection}

The study protocol was approved by the local ethical review committee and informed consent was obtained from 97 participating pregnant women (age: $37 \pm 10$ years) recruited in Aquitaine between 1997 and 1999. The health state of these mothers needed a childbirth (38-42 postmenstrual weeks) by caesarean surgery.

During caesarean surgery, maternal peripheral venous blood and subcutaneous adipose tissue were removed. Cord vein blood was drawn by venipuncture from the placental portion of the umbilical cord, immediately after its clamping. Clinical data concerning the mother (age, tabbaco consumption...) and the term-born infant (height, weight, head perimeter) were registered by doctor, in a book. RBC were separated from plasma by centrifugation and umbilical cord samples were immediately rinsed with an isotonic saline solution $(0.9 \% \mathrm{NaCl})$ and then frozen and stored at $20^{\circ} \mathrm{C}$ until analyzed.

\section{Analytical procedure}

Thawed samples of plasma, adipose tissue and umbilical tissues were ground in a mixture of chloroform/methanol (2:1, by vol). Total lipids were extracted from samples according to the Folch method [24]. Solvents were evaporated to dryness under a stream of nitrogen. Lipids were taken up in an appropriate volume of chloroform/methanol $\left(2: 1\right.$, by vol) and stored in glass tubes at $-20^{\circ} \mathrm{C}$ under nitrogen. Plasma triglycerides (TG), cholesterol esters (CE) and total phospholipids (TPL) were separated by thin layer chromatography using hexane/diethyl ether/acetic acid (90:10:1, by vol). 
Fatty acids methyl esters (FAME) of total lipids and fractionated lipids were prepared with $14 \%$ boron trifluoride in methanol according to Morrison and Smith [25] and stored in hexane, at - $20^{\circ} \mathrm{C}$ under nitrogen.

Analyses of total FAME were carried out on a gas chromatograph (GC) (Carlo Erba 5160, Milano, Italy) equipped with a flame-ionization detector and a split injector. A fused-silica capillary column (BPX 70, $60 \mathrm{~m} \times 0.25 \mathrm{~mm}$ i.d., 0.25 mum film; SGE, France) was used with $\mathrm{H}_{2}$ as a carrier gas (inlet pressure: $90 \mathrm{kPa}$ ). The split ratio was $1 / 70$. The column temperature was programmed from 150 to $200^{\circ} \mathrm{C}$ at $1.5^{\circ} \mathrm{C} / \mathrm{min}$, then to $230^{\circ} \mathrm{C}$ at $2.5^{\circ} \mathrm{C} / \mathrm{min}$ and held at $230^{\circ} \mathrm{C}$ until completion of the analysis (30 min). The injection port and the detector were maintained at $250^{\circ} \mathrm{C}$. The gas chromatographic peaks were integrated using a SP 4400 integrator (Spectra Physics, San Jose, CA).

All the results are expressed as weight percentages of fatty acids using the factor ( $\left.F^{\prime} t\right)$ described by Wolff et al. [26]. This factor is linked to the theoretical response factor (Ft) by: $\mathrm{F}^{\prime} \mathrm{t}=\mathrm{Ft} \mathrm{x}$ (fatty acid molecular weight/FAME molecular weight).

\section{Results and discussion}

\section{Comparison of TFA composition of mother and fetus plasma (Figure 1)}

Trans fatty acid (TFA) percentage was significantly higher $(p=0.001)$ in maternal $(0.9 \%$ of total fatty acids) than in umbilical plasma total lipids (0.6\%).

This result is different from that found in a German study describing occurrence of TFA in cord plasma [22], at percentage level similar to that in the mothers. However, in that study, TFA contents of umbilical and maternal plasma total lipids were two times higher than values observed here, which was probably due to a higher intake of TFA in German women than in French, at the time of these studies.

As shown in the Figure 1, trans isomer pattern in cord plasma lipids was different from the maternal's one. Trans $18: 1$ acid level in maternal plasma $(0.64 \%$ of total fatty acids) exceeded significantly $(\mathrm{p}<0.001)$ that found in umbilical plasma $(0.24 \%)$, while trans $18: 2$ acid percentage was significantly higher $(p<0.001)$ in umbilical $(0.30 \%)$ than in maternal plasma $(0.16 \%)$. More precisely, $9 t 12 c-18: 2$ isomer and $9 c 13 t+9 t 12 t-18: 2$ isomer mix amounts were significantly higher $(p<0.001)$ in umbilical (respectively, 0.15 and $0.08 \%$ of total fatty acids) than in maternal plasma (respectively, $0.05 \%)$. Whereas no difference was observed between these two compartments with respect to $9 c 12 t-18: 2$ isomer level (respectively, $0.06 \%$ of total fatty acids in maternal plasma and $0.07 \%$ in umbilical plasma).

The occurrence of TFA in cord plasma confirms the transplacental transport of the different trans isomers. Nevertheless, the prevalence of trans 18:2 isomers and more precisely of 9t12c-18:2 isomer in umbilical plasma may be explained either by a preferential transfer of this isomer across the placenta, as a consequence of sequestration process, or by an accumulation in cord plasma linked to bad metabolization of this isomer by the fetus compared with the other trans 18:2 isomers. 
The placental enzyme behaviour towards trans 18:2 isomers was examined through the incorporation level of these trans diene isomers into the lipid classes of cord plasma.

\section{TFA incorporation into different lipid classes of umbilical plasma (Figure 2)}

Trans 18:2 isomers occurred in the three main umbilical plasma lipid classes, but the relative percentage values of these trans diene isomers were significantly lower $(p<0.001)$ in total phospholipids (TPL) $(0.14 \%$ of total fatty acids) than in triglycerides (TG) $(0.41 \%)$ or in cholesterol esters (CE) (0.41\%).

Moreover, these three classes of plasma lipids standed out by differences in their proportions of various trans $18: 2$ isomers. TPL and CE were characterized by $9 t 12 c$ isomer prevalence (respectively, 47 and $48 \%$ of total trans $18: 2$ acids), followed by the mix $9 c 13 t+9 t 12 t$ and $9 c 12 t$ (respectively, 29 and $24 \%$ ) in TPL and by $9 c 12 t$ and the mix $9 c 13 t+9 t 12 t$ (respectively, 32 and $20 \%$ ) in EC. Whereas in TG, the three trans 18:2 isomers were present in equivalent proportions (31 to $38 \%$ of total trans 18:2 acids). This finding may be explained by the metabolism of cholesterol. Fatty acid pattern of CE illustrates that of sn-2 position of phosphatidylcholine (PC), since CE are generated by activity of lecithin-cholesterol-acyl-transferase (LCAT) which transfers fatty acids from PC sn-2 position to cholesterol [27]. It is known [28] that $100 \%$ of $9 t 12 c$ and $77 \%$ of $9 c 12 t$ isomers are incorporated into the sn-2 position of maternal PC, whereas $75 \%$ of $9 c 13 t+9 t 12 t$ isomers mix are present in sn- 1 of PC. Consequently, if it is also true for the cord plasma PC, then it could explain the preferential incorporation of $9 t 12 c$ and secondly $9 c 12 t$ into CE.

Incorporation of the maternal TFA isomers into phospholipids of umbilical blood and red blood cells (RBC) (Figures 3 and 4)

As shown in Figure 3, TFA percentage was significantly lower $(p=0.003)$ in umbilical RBC $(0.25 \%$ of total fatty acids) than in umbilical plasma TPL (0.42\%). Nevertheless, TFA patterns of these two compartments were similar. Trans 18:1 isomers contributed to the major portion to total TFA (55\% of total TFA) in both RBC and plasma TPL. However, trans 18:2 acid level was significantly lower ( $p=$ $0.011)$ in RBC $(0.10 \%$ of total fatty acids) than in plasma TPL $(0.14 \%)$. Moreover, trans $18: 2$ acid profiles (Figure 4) were different in these two compartments. Although the three trans 18:2 isomer proportions were equivalent ( 37 to $40 \%$ of total trans $18: 2$ acids) in TPL of RBC, $9 t 12 c$ isomer predominated $(47 \%)$ over $9 c 13 t+9 t 12 t$ isomer mix $(29 \%)$ and $9 c 12 t$ isomer $(24 \%)$ in plasma TPL.

\section{Maternal TFA incorporation into phospholipids of cord and vessel walls (Figure 5)}

After having investigated TFA incorporation into both plasma and RBC lipids of cord vein blood, our attention was then paid to the TFA incorporation into TPL of umbilical cord parietal tissue and umbilical vessels.

Except trans 16:1 acids, all trans isomers already seen in umbilical plasma were detected in both parietal and vessel TPL of umbilical cord. TFA content, all isomers confounded, of cord wall TPL ( $0.31 \%$ of total fatty acids) didn't differ significantly from that found in cord vein $(0.28 \%)$ or artery TPL (0.35\%). Nevertheless, proportions of trans $18: 1$ and 18:2 isomers were similar (respectively, 48 and $52 \%$ of total fatty acids) in cord wall and vein TPL, whereas in artery TPL, trans 18:2 isomers predominated ( $68 \%$ of total TFA) significantly $(p=0.001$ ) over trans $18: 1$ isomers ( $32 \%$ of total TFA). 
Furthermore, these three compartments of umbilical cord (parietal tissue, vein and artery) were characterized by prevalence of $9 c 13 t+9 t 12 t$ isomers compared with the other trans 18:2 isomers. Nevertheless, the isomer mix level was significantly higher $(p<0.001)$ in artery TPL $(0.17 \%$ of total fatty acids) than in vein TPL $(0.09 \%)$, itself significantly higher $(p=0.005)$ than in cord wall TPL (0.06\%).

Moreover, in artery TPL, percentage value of $9 c 13 t+9 t 12 t$ isomer mix was inversely correlated $(r=-$ $0.703, p=0.003$ ) with arachidonic acid (AA) content, but not with that of linoleic acid (LA), precursor of AA. This result is in agreement with the inverse relation observed between TFA and LC-PUFA in umbilical plasma lipids of both healthy children [29] and preterm infant [22]. This inverse relation was also verified between trans 18:1 isomer and the n-6 LC PUFA in human fetal tissue collected after abortions (gestational age 5-15 weeks) [23].

If we admit that fatty acid pattern of umbilical artery TPL reflects that of fetal tissue TPL, then these results could demonstrate a potential impairment by $9 c 13 t+9 t 12 t$ isomer mix of LA metabolism, or preferential uptake of maternal plasma AA by the placenta. Major part of LC-PUFA found in fetal tissues comes from maternal blood, because placental delta6 desaturase activity is too poor to provide sufficiently LC-PUFA for fetus development [30]. Nevertheless, concerning AA, selective transplacental transport is supposed to be less important than fetal synthesis [31], thus interference of $9 c 13 t+9 t 12 t$ isomer mix with delta6 desaturase activity could be the best explanation to our results. Insofar as AA is of great physiological importance during fetal development as essential membrane component of neural tissues and as precursor for eicosanoid synthesis, it could be assumed that accumulation of these trans dienes might have side effects on fetus development. However, these results must be considered with a lot of caution, since it concerns the mix of different trans $18: 2$ isomers.

Some studies $[22,23]$ have suggested that exposure to high levels of TFA during pregnancy may affect intrauterine human growth, in particular birth weight and head circumference.

So, after examination of TFA incorporation into umbilical plasma lipids and TPL of cord and vessel walls, we have devoted us to assess, for these French pregnant women, potential impact of their TFA intake during pregnancy on either weight or head circumference of newborn.

\section{Relation between newborn anthropometric parameters and TFA levels in maternal and umbilical plasma (Figures 6 to 9)}

Because TFA content of adipose tissue is a reliable biochemical indicator of the usual TFA intake level $[32,33]$, we studied newborn anthropometric parameters in relation to TFA level of maternal adipose tissue lipids (Figures 6 and 7). Based on dietary questionnaire, we found that average TFA consumption of this pregnant women population was $3.1 \pm 1.2 \mathrm{~g} / \mathrm{d} /$ pers., ranging from 0.9 to $6.5 \mathrm{~g} / \mathrm{d} /$ pers. (or 0.5 to $2.5 \%$ of total energy intake). No correlation was observed between TFA level of maternal adipose tissue and either newborn weight (Figure 6) or head circumference (Figure 7). Correlation absence persisted even after having applied corrections which took account of confounding factors such as mother's age, BMI and possible tabacco consumption. 
This first result shows that TFA intake level of these French pregnant women seems to be sufficiently low to induce no growth failure.

However, we have verified in the second time if TFA amount, transferred across the placenta from maternal plasma lipids, could be put in relation to previous antropometric parameters (Figures 8 and 9). As for the adipose tissue, we noticed that TFA level of maternal plasma lipids was related to neither newborn weight (Figure 8) nor head circumference (Figure 9), even after multifactorial corrections.

Our results do not agree with those reported by Koletzko et al. [22] who demonstrated negative correlations between birth weight of premature infant and percentage of either total TFA in umbilical TPL or trans 18:1 acid percentage in CE. Similarly, Van Houvelingen et al. [23] have also observed inverse relation between trans 18:1 acid in umbilical arterial vessel walls and weight and head circumference of full-term neonates.

This discrepancy might be explained by sensitivity to TFA in full-term lower than in preterm infant whose LC-PUFA stores are extremely more limited compared to term infant [29], and by TFA intake of mothers which was higher in Germany and Netherlands than in Aquitaine [34].

\section{CONCLUSION}

In summary, we observed differences in TFA proportions between maternal and cord plasma total lipids. These data could demonstrate either potential discriminating placental transport of different TFA isomers or metabolism selectivity of different TFA isomers by the fetus. Trans isomers were incorporated not only into lipids of cord blood (plasma and RBC) afferent to fetus but also into TPL of parietal tissue and vessels of umbilical cord. Moreover, inverse correlation found between $9 c 13 t+$ $9 t 12 t$ isomer mix and AA levels in artery TPL suggested that these trans 18:2 isomers might enhance LC-PUFA deficiency of fetus. However, this hypothese must be supported by further investigations since it concerns mix of different trans 18:2 isomers.

Finally, TFA intake level of these French pregnant women, assessed to 3.1 gram per day, seems to be sufficiently low not to affect negatively weight and head circumference of newborn.

\section{Acknowledgments}

The authors gratefully acknowledge the expert technical assistance of Laurence Fonseca and Pascale Nonatel. The work was supported by grants from ONIDOL (Organisation nationale interprofessionnelle des oléagineux). 


\section{REFERENCES}

1. WOLFF RL, PRECHT D, MOLKENTIN J (1998). Occurrence and distribution profiles of trans 18:1acids in edible fats of natural origin. In: SÉBÉDIO JL, CHRISTIE WW, eds. Trans fatty acids in human nutrition. Great Britain: Oily Press, 1-33.

2. CRAIG-SCHMIDT MC (1992). Fatty acid isomers in foods. In: CHOW CK, ed. Fatty acids in foods and their health implications. New York: M Dekker, 365-98.

3. WOLFF RL (1993). Heat induced geometrical isomerisation of alpha-linolenic acid: effect of temperature and heating time on the appearance of individual isomers. J Am Oil Chem Soc, 70: 42530.

4. ANDERSON RL, FULLNER CS, HOLLENBACH EJ (1975). Effects of the trans isomers of linoleic acid on the metabolism of linoleic acid in rats. J Nutr, 105: 393-400.

5. PRIVETT OS, STEARNS EMJ, NICKELL E (1967). Metabolism of the geometric isomers of linoleic acid in the rat. J Nutr, 92: 303-10.

6. BERDEAUX O, SÉBÉDIO JL, CHARDIGNY JM, et al. (1996). Effects of trans n-6 fatty acid profile of tissues and liver microsomal desaturation in the rat. Grasas Aceit, 47: 86-99.

7. MAHFOUZ MM, SMITH TL, KUMMEROW FA (1984). Effects of dietary fats on desaturase activities and the biosynthesis of fatty acids in liver microsomes. Lipids, 19: 214-22.

8. COOK HW, EMKEN EA (1990). Geometric and positional fatty acid isomers interact differently with desaturation and elongation of linoleic acid in cultured glioma cells. Cell Biol, 68: 653-60.

9. BERDEAUX O, BLOND JP, BRETILLON L, et al. (1998). In vitro desaturation or elongation of mono trans isomers of linoleic acid by rat liver microsomes. Mol Cell Biochem, 185: 17-25.

10. BLOND JP, CHARDIGNY JM, SÉBÉDIO JL, GRANDGIRARD A (1995). Effects of dietary 18:3n-3 isomers on the delta6 desaturation of alpha-linolenic acid. J Food Lipids, 2: 99-106.

11. ROSENTHAL M, DOLORESCO MA (1984). The effects of trans fatty acids on fatty acyl delta5 desaturation by human skin fibroblasts. Lipids, 19: 869-74.

12. SHIMP JL, BRUCKNER G, KINSELLA JE (1982). The effects of dietary trilinelaidin on fatty acid and acyl desaturases in rat liver. J Nutr, 112: 722-35.

13. HWANG DH, KINSELLA JE (1979). The effect of trans, trans methyl linoleate on the concentration of prostaglandins and their precursors in rat. J Nutr, 17: 543-60.

14. BRENNER RR, PELLUFO RO (1969). Regulation of unsaturated fatty acid biosynthesis. I/ Effect of unsaturated fatty acid of 18 carbons on the microsomal desaturation of linoleic acid into gammalinolenic acid. Biochim Biophys Acta, 176: 471-9.

15. ZEVENBERGEN JL, HOUTSMULLER UM, GOTTENBOS JJ (1988). Linoleic acid requirement of rats fed trans fatty acids. Lipids, 23: 178-86. 
16. ZEVENBERGEN JL, HADDEMAN E (1989). Lack of effects of trans fatty acids on eicosanoid biosynthesis with adequate intakes of linoleic acid. Lipids, 24: 555-63.

17. INNIS SM, SPRECHER H, HACHEY D, EDMOND J, ANDERSON RE (1999). Neonatal polyunsaturated fatty acid metabolism. Lipids, 34: 139-49.

18. CLANDININ MT (1999). Brain development the supply of polyunsaturated fatty acid. Lipids, 34: 131-7.

19. CARLSON SE, NEURINGER M (1999). Polyunsaturated fatty acid status and neurodevelopment: a summary and critical analysis of the literature. Lipids, 34: 171-8.

20. SELLMAYER A, KOLETZKO B (1999). Long chain polyunsaturated fatty acids and eicosanoids in infants physiological and pathophysiological aspects and open questions. Lipids, 34: 199-205.

21. KUHN DC, CRAWFORD M (1986). Placental essential fatty acid transport and prostaglandin synthesis. Prog Lipid Res, 25: 345-53.

22. KOLETZKO B (1992). Trans fatty acids may impair biosynthesis of long-chain polyunsaturates and growth in man. Acta Paediatr, 81: 302-6.

23. VAN HOUVELINGEN AC, HORNSTRA G (1994). Trans fatty acids in early development. World Rev Nutr Diet, 75: 175-8.

24. FOLCH J, LEES M, SLOANE-STANLEY GH (1957). A simple method for the isolation and purification of total lipids from animal tissus. J Biol Chem, 226: 497-509.

25. MORRISON WR, SMITH LM (1964). Preparation of fatty acid methyl esters and dimethylacetals with boron fluoride methanol. J Lipid Res, 5: 600-8.

26. WOLFF RL, BAYARD CC, FABIEN RJ (1995). Evaluation of sequential methods for the determination of butterfat fatty acid composition with emphasis on trans-18:1 acids: application to the study of seasonal variations in French butters. J Am Oil Chem Soc, 72: 1471-83.

27. JONAS A (1991). Lecithin: cholesterol acyltransferase in the metabolism of high density lipoproteins. Biochim Biophys Acta, 1084: 205-20.

28. BOUÉ C (2000). Étude, chez des femmes d'Aquitaine, de la consommation d'acides gras trans et de leur devenir métabolique en relation avec le risque cardiovasculaire. Thèse Université de Bordeaux-I, 1-163.

29. DECSI T, KOLETZKO B (1995). Do trans fatty acids impair linoleic acid metabolism in children. Ann Nutr Metab, 39: 36-41.

30. DEMMELMAIR H, VON SCHENCK KU, BEHRENDT E, SAUERWALD T, KOLETZKO B (1995). Estimation of arachidonic acid synthesis in fullterm using nautral variation of ${ }^{13} \mathrm{C}$-abundance. $J$ Ped Gastro Nutr, 21: 31-6. 
31. HAGGARTY P, PAGE K, ABRAMOVICH DR, ASHTON J, BROWN D (1997). Long chain polyunsaturated fatty acid transport across the perfused human placenta. Placenta, 18: 635-42.

32. LONDON SJ, SACKS FM, CAESAR J, STAMPFER MJ, SIGUEL E, WILLETT WC (1991). Fatty acid composition of subcutaneous adipose tissue and diet in postmenopausal US women. Am J Clin Nutr, 54: 340-5.

33. ENIG MG, ATAL S, KEENEY M, SAMPUGNA J (1990). Isomeric trans fatty acids in the US diet. J Am Coll Nutr, 9: 471-86.

34. CRAIG-SCHMIDT MC (1998). Worldwide consumption of trans fatty acids. In: SÉBÉDIO JL, CHRISTIE WW, eds. Trans fatty acids in human nutrition. Great Britain : Oily Press, 59-113.

Illustrations

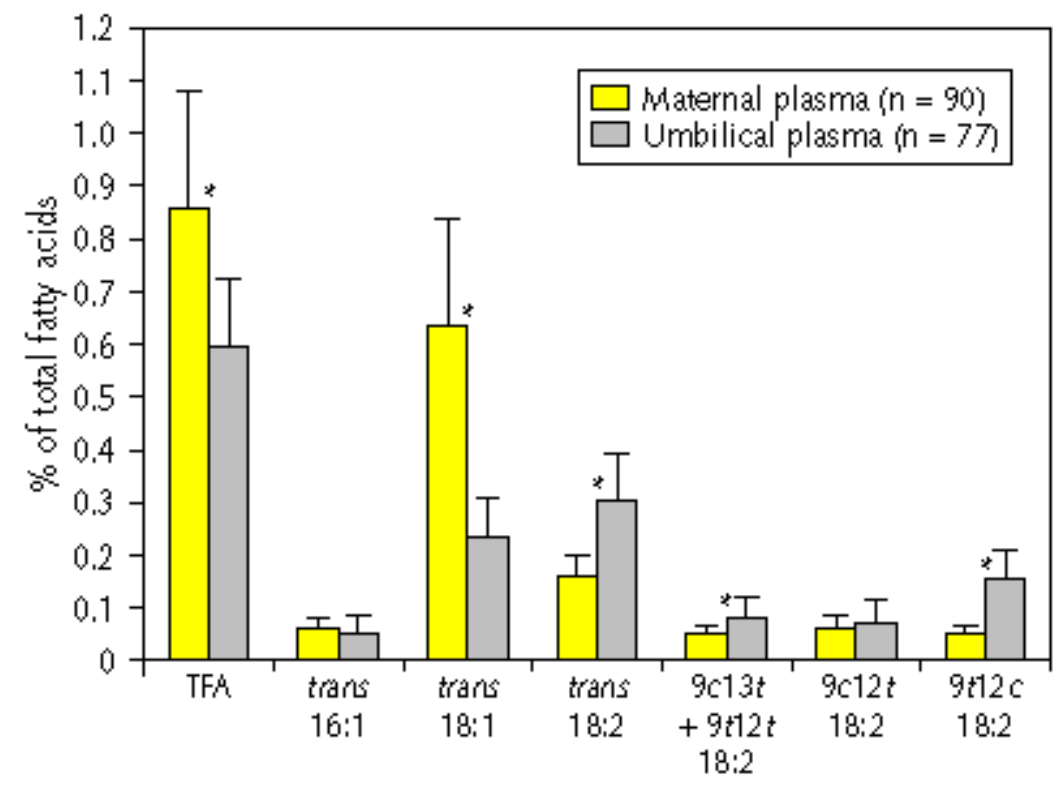

Figure 1. Trans fatty acid (TFA) composition (\% weight) of maternal and umbilical plasma total lipids (* $p<0.001)$. 


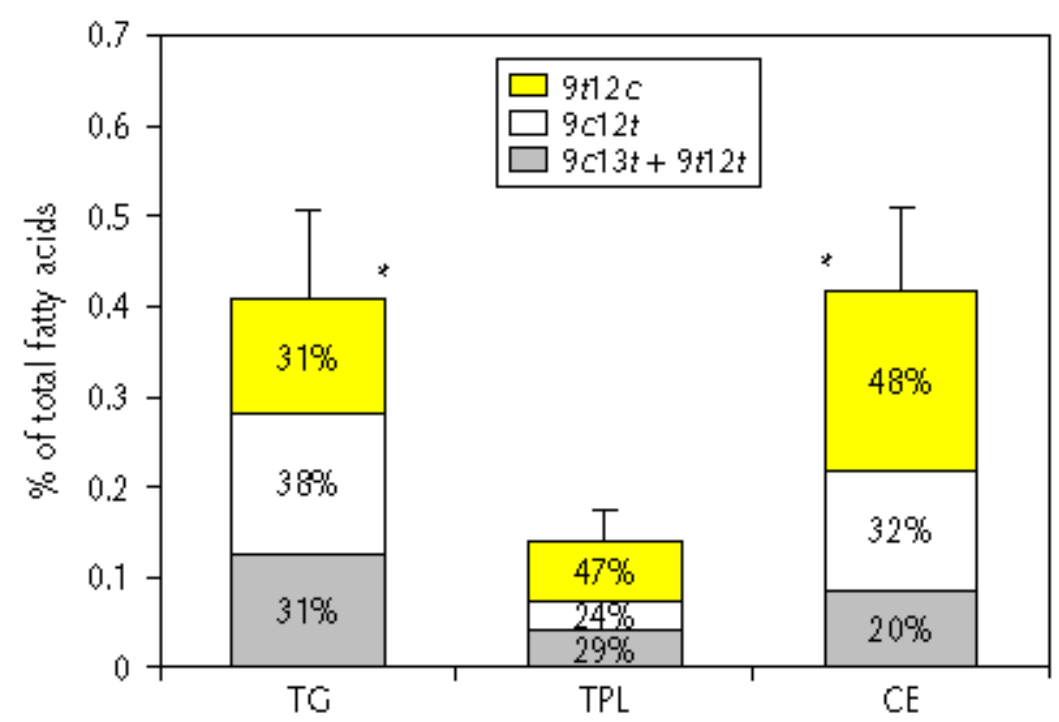

Figure 2. Proportion of the different trans 18:2 isomers in triglycerides (TG) ( $n=$ 32), total phospholipids (TPL) $(n=62)$ and cholesterol esters (CE) $(n=40)$ of umbilical plasma (* $p<0.001)$.

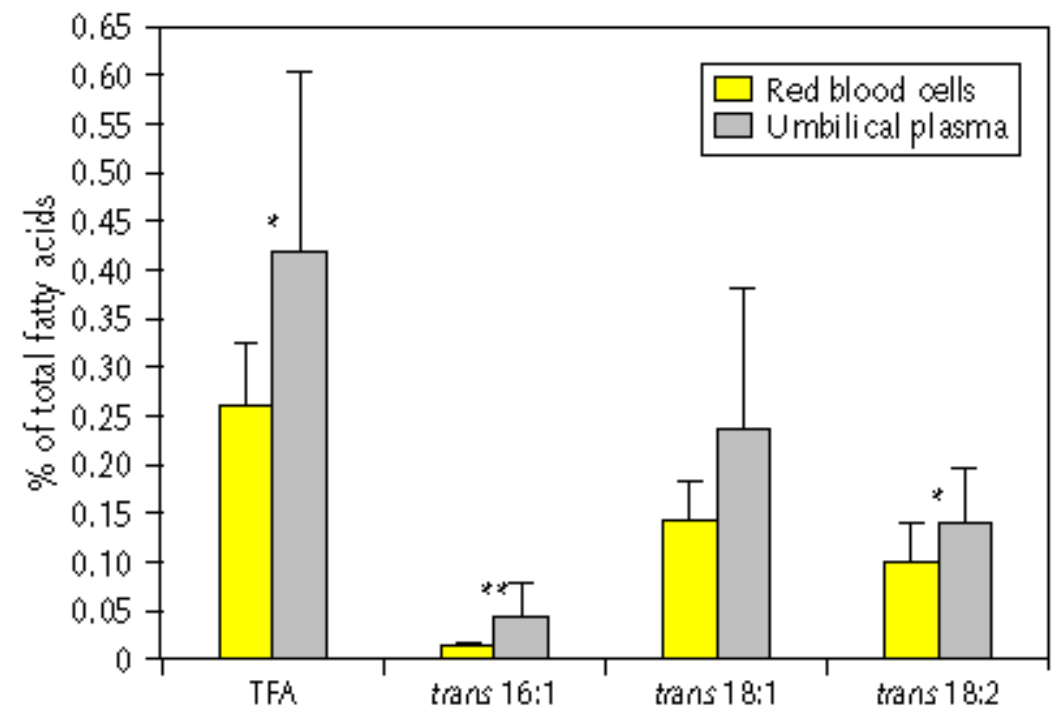

Figure 3. Trans fatty acid (TFA) composition (\% weight) of umbilical red blood cell $(n=11)$ and plasma total phospholipids $(n=62)\left({ }^{*} p<0.01,{ }^{* *} p<0.001\right)$. 


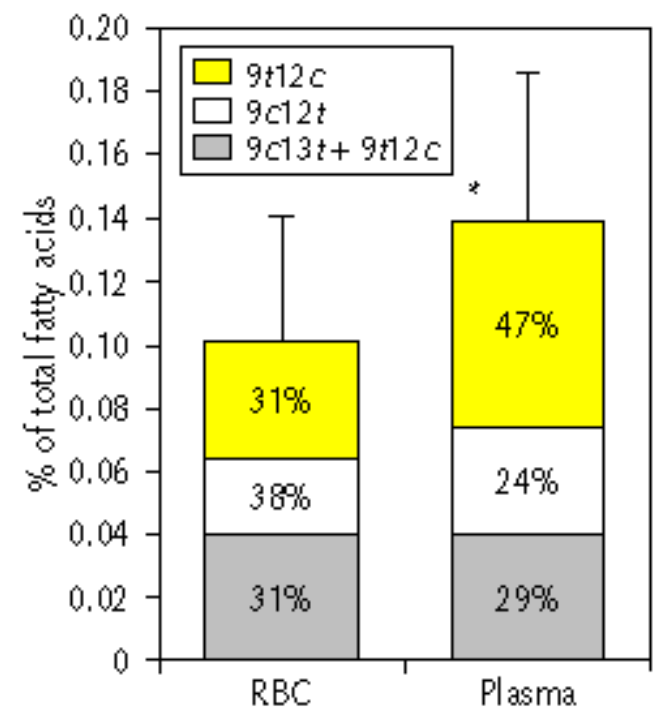

Figure 4. Trans 18:2 isomer pattern of umbilical red blood cell $(R B C)(n=11)$ and plasma $(n=62)$ total phospholipids ( $\left.{ }^{*} p<0.01\right)$.

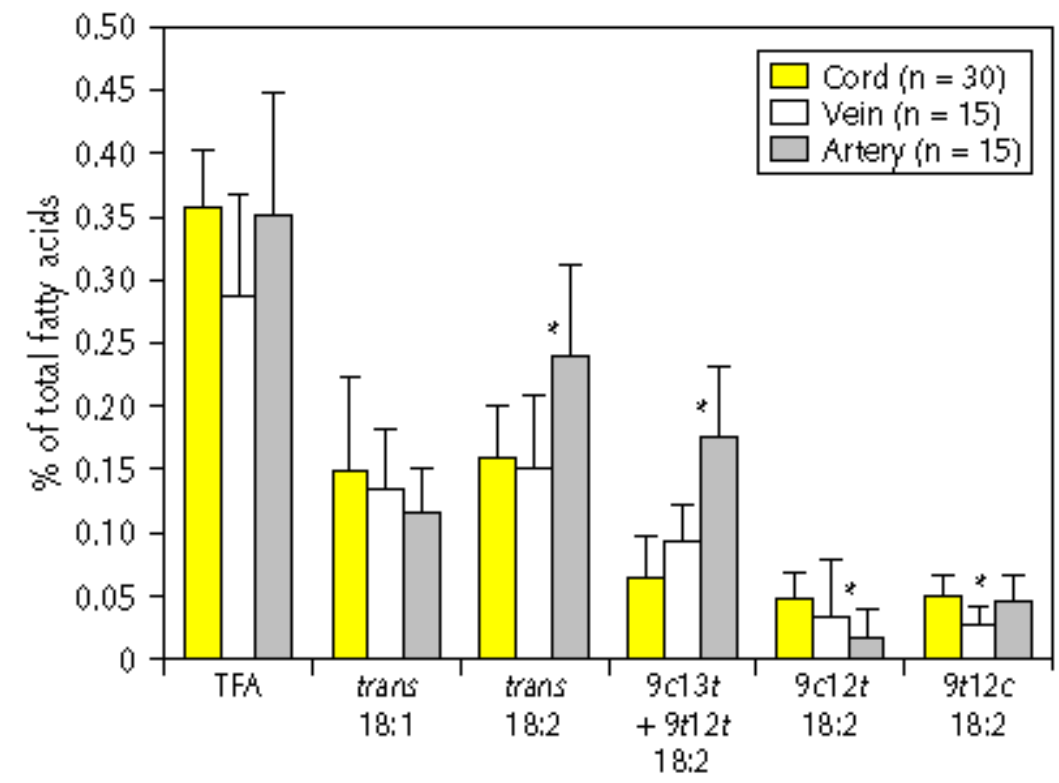

Figure 5. Trans fatty acid (TFA) composition (\% weight) of cord wall, vein and artery total phospholipids $(* p<0.001)$. 


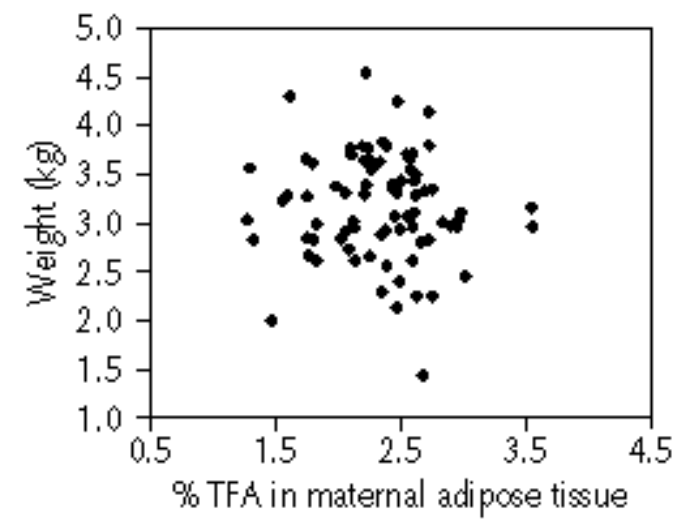

Figure 6. Correlation between newborn weight $(\mathrm{kg})$ and TFA percentage in maternal adipose tissue $(n=81)$.

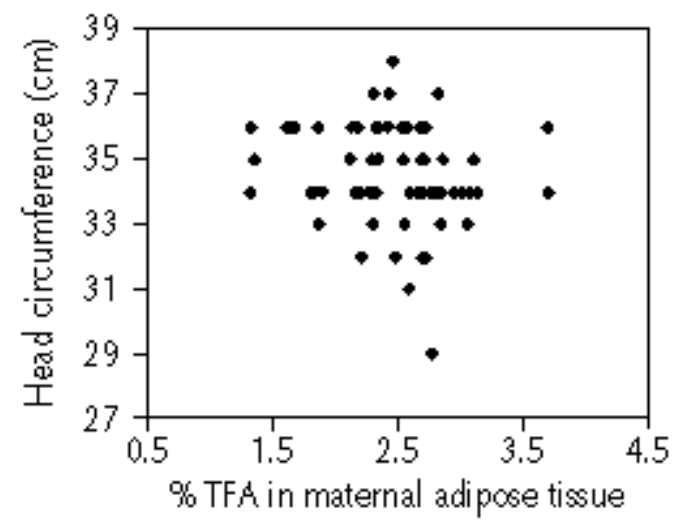

Figure 7. Correlation between newborn head circumference (cm) and TFA percentage in maternal adipose tissue $(n=68)$. 


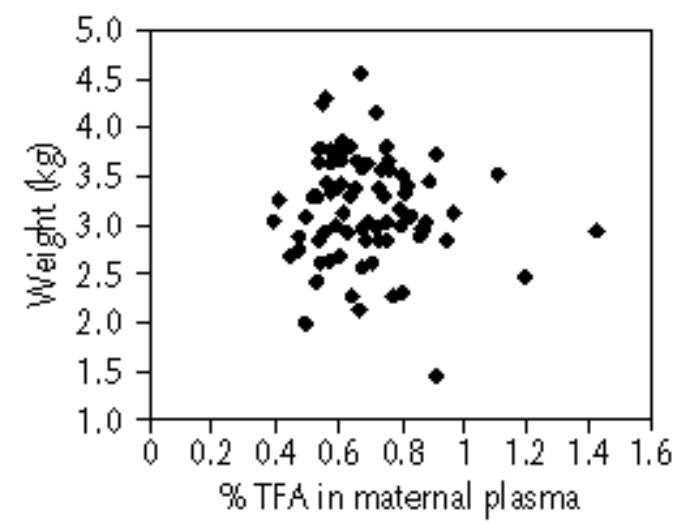

Figure 8. Correlation between newborn weight $(\mathrm{kg})$ and TFA percentage in maternal plasma $(n=81)$.

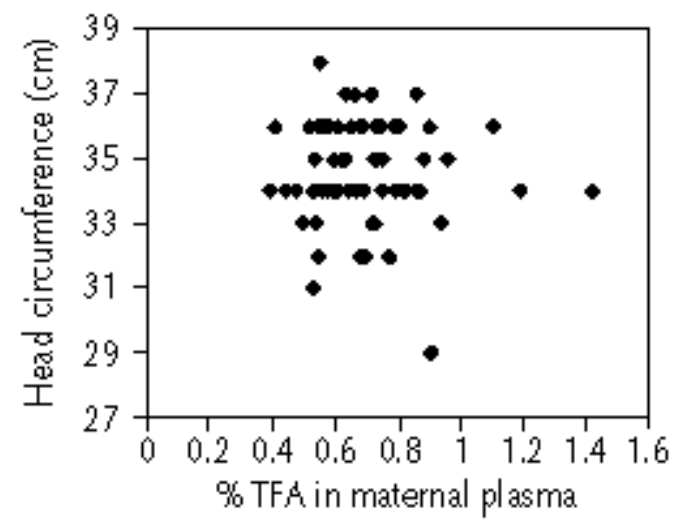

Figure 9. Correlation between newborn head circumference $(\mathrm{cm})$ and TFA percentage in maternal plasma $(n=68)$. 